\title{
A review on effects of conjugated linoleic fatty acid (CLA) upon body composition and energetic metabolism
}

\author{
Tatiana Ederich Lehnen ${ }^{1,4}$, Marcondes Ramos da Silva ${ }^{2}$, Augusto Camacho ${ }^{1,2}$, Aline Marcadenti ${ }^{2,3}$ \\ and Alexandre Machado Lehnen ${ }^{1,2^{*}}$
}

\begin{abstract}
Conjugated linoleic acid (CLA) is highly found in fats from ruminants and it appears to favorably modify the body composition and cardiometabolic risk factors. The capacity of CLA to reduce the body fat levels as well as its benefic actions on glycemic profile, atherosclerosis and cancer has already been proved in experimental models. Furthermore, CLA supplementation may modulate the immune function, help re-synthetize of glycogen and potentiate the bone mineralization. CLA supplementation also could increase the lipolysis and reduce the accumulation of fatty acids on the adipose tissue; the putative mechanisms involved may be its action in reducing the lipase lipoprotein activity and to increase the carnitine-palmitoil-transferase-1 (CAT-1) activity, its interaction with PPARY, and to raise the expression of UCP-1. Although studies made in human have shown some benefits of CLA supplementation as the weight loss, the results are still discordant. Moreover, some have shown adverse effects, such as negative effects on glucose metabolism and lipid profile. The purpose of this article is to review the available data regarding the benefits of CLA on the energetic metabolism and body composition, emphasizing action mechanisms.
\end{abstract}

\section{Introduction}

Although many research studies are inconclusive about functional foods, their benefits to health have often been discussed, calling the attention of the scientific community [1-3]. Thus, several studies were performed claiming that functional foods are essential for health and have helped reduce the risk of developing various chronic diseases [4-6]. This functional property concerns the metabolic or physiological role played by the nutrient or non-nutrient in growth, development, maturity and other normal functions of the human organism. However, studies on nutraceutics (foods with a medicinal function) lack further explanation, especially regarding the associated protective effects. The doses indicated generate doubts that these effects will be achieved, and also regarding the possible adverse effects of their long term use [1-3].

\footnotetext{
* Correspondence: amlehnen@gmail.com

'Faculdade Sogipa de Educação Física, Porto Alegre, Brazil

${ }^{2}$ Instituto de Cardiologia/Fundação Universitária de Cardiologia (IC/FUC),

Porto Alegre, Brazil

Full list of author information is available at the end of the article
}

Several classes of substance which are naturally present in foods or produced by food technology have functional properties. One of these substances is conjugated linoleic acid (CLA) - a fatty acid which presents a linoleic acid isomer (C18:2, n-6) and has been considered an antiobesity agent, and can be useful in the weight reduction process [7]. Although the initial results were found only in an animal model $[8,9]$, more recent research on humans suggests that CLA would act to reduce adiposity through modulating properties in the lipid metabolism [10, 11]. However, doubts remain as to the action mechanisms of CLA in adipocytes, leading to the reduction of body fat and, especially, the safety of supplementation of this compound.

Therefore, the purpose of this review is to describe the effect of CLA supplementation on body composition, particularly on the reduction of adiposity, focusing on possible action mechanisms. 


\section{Conjugated linoleic acid}

Conjugated linoleic acid (CLA) is a term that describes a group of fatty acids with 18 atoms of carbon, and the geometric isomers consist of linoleic acid [12]. This is a common name given to a group of position isomers with two double bonds separated by a methylene group [7, 13]. This conjugation of the double bond is generally in positions 9 and 11 or 10 and 12, and may be a cis or trans configuration (Fig. 1).

CLA is produced naturally in the digestive tract of ruminants such as cattle, goats, sheep, buffalo, and to a lesser degree in pigs, chickens and turkeys, and the synthesis occur due to fermentative bacteria, Butyrivibrio Fibrisolvens, which isomerize the linoleic acid in CLA or by synthesis via $\alpha 9$-desaturase of 11-trans octadecanoic acid [14]. The fat in beef contains about 1.7 to $10.8 \mathrm{mg}$ CLA/g of fat with 9-cis and 11-trans isomers. It is also found in dairy products (milks and derivatives) [6].

CLA can be obtained by means of enzyme $\alpha 9$ desaturase which promotes the desaturation of the 11trans octadecanoic acid. Several different isomers of CLA such as 11-trans and 9-cis are the best known because they are found in food $[7,12]$. It is also possible to obtain CLA in an industrial form, through the partial hydrogenation of linoleic acid or by thermal treatments, aiming to produce a compound with maximum biological activity and with a defined chemical composition [10].

CLA has a major role in the lipid metabolism, especially as regards the oxidative cellular system, which explains many physiological properties of fatty acids. Their

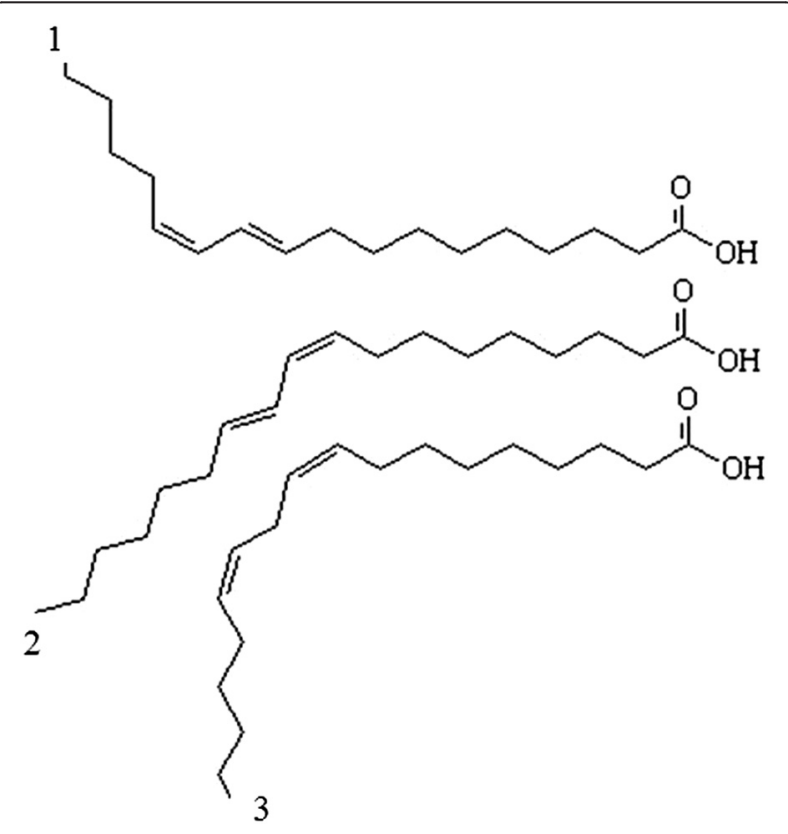

Fig. 1 Isomer structure. (1) represents CLA 10-trans and 12-cis; (2) indicate CLA 9-cis and 11-trans; (3) C18:2 9-cis and 12-cis action on the lipid metabolism is associated with the inhibition of the entry of glucose into the adipocytes, and may lead to changes in the insulin metabolism and cause situations of hyperinsulinemia, as well as the increase of inflammatory markers $[15,16]$.

There are many investigations to evaluate the influences of CLA on the energetic metabolism, promoting significant changes in the lipid metabolism and in body composition [9-11, 17-20]. As a result, some effects can be cited such as: reduction of body fat, improved insulin resistance, antithrombogenic and anticarcinogenic effects, reduction of atherosclerosis, improved lipid profile, modulation of the immune system and stimulation of bone mineralization, and also reduced blood glucose. The most studied CLA supplementation effect is its capacity to alter the body composition, promoting an increase in lean mass and reduction of the fatty mass.

\section{Putative mechanisms of action}

The possible action mechanisms which show that CLA can alter the body composition involve metabolic changes that favor the reduction of the lipogenesis and the potentiation of lipolysis, accompanied by the oxidation of fatty acid in the skeletal muscle, due to increased carnitine palmitoil-transferase- 1 activity and action, or possibly because of adipocyte differentiation inhibition [7]. Therefore, researchers have evaluated the action of CLA supplementation on the lipid and hormone profile, and the activity of the enzymes involved in the oxidation process [21].

Studies have demonstrated that isomers 10-trans and 12-cis, differently from the 9-cis 11-trans of CLA, increase lipolysis significantly in the human adipocytes, and also have the function of diminishing the synthesis of fatty acids [15]. This would explain, in part, the possible action mechanisms of CLA on the body composition. Although various studies were in vitro, the metabolic hypotheses to explain the body fat reducing action of CLA began based on control of the expression of genes involved in the differentiation of pre-adipocytes into mature adipocytes, in other words, the expression of these genes would result in reducing lipogenesis [22, 23].

In turn, the peroxisome proliferator-activated receptors (PPARs) are nuclear transcription factors that play a central role in the storage and catabolism of fatty acids (FA). They are part of a class of nuclear receptors that belong to the family of the nuclear receptor of the steroid, retinoid and thyroid receptors. Three isoforms of the nuclear receptor have already been identified, PPAR $\alpha$, PPAR $\beta$ and PPAR $\gamma$. PPAR $\alpha$ and $\beta$ are involved in the lipid metabolism (especially the proteins related to FA oxidation) and glucose, and PPARY is involved in adipocyte differentiation $[24,25]$. 
Figure 2 shows the activation mechanism and requires the release of the co-repressor complex (histone deacetylase activity) by a binder, and the recruitment of the co-activator complex (acetyltransferase activity). The activated PPAR:RxR complex binds to the elements that are responsive to peroxisome proliferators (PPRE), producing changes in the chromatin structure, giving rise to a transcriptionally competent structure. Hence, it seems that the CLA interacts with the Co-activator complex PPAR increasing the gene transcription related to the differentiation of adipocytes, lipolysis ( $\beta$-oxidation), mitochondrial biogenesis and insulin sensitivity, and collectively, it is related to the weight loss effect [24].

The effects of CLA in lipid and glucose metabolism on body composition are mediated by the activation or inhibition of the PPARs, especially PPAR . The inhibition of PPAR $\gamma$ by CLA (isomer 10-trans, 12-cis) leads to the reduction of body fat by modulation of the gene expression in the sense that it inhibits cell differentiation and alters the activity of proteins involved in lipogenesis and in lipolysis [26]. Evidence suggests that the activation of PPAR $\gamma$ can diminish the progression of atherosclerosis and increase sensitivity to insulin, and may be a potential therapeutic target for the treatment of various diseases, including diabetes mellitus type 2 (DM2) and dyslipidemia.

In adipocytes, PPARY regulates the expression of genes involved in the lipid metabolism, including acyl CoAsynthetase and lipoprotein lipase (LPL). The expression of the transport protein of fatty acids involved in the uptake of lipids by the adipocytes is also controlled by PPAR $\gamma$ [25].

The reduction of body fat occurs not due to the reduction in the number of adipocytes but rather by the reduction of their size. Considering that the size of the adipose cells is directly elated to the triglyceride content inside the cells, its reduction results in a smaller cell size. The increased $\beta$-oxidation of mitochondrial fatty acids induced by CLA may be responsible for the reduction of triacylglycerol synthesis, not depositing them in the adipocyte, but reducing their size [8].

The fatty acid is transported into the mitochondria by the carnitine-palmitoil-transferase (CPT) complex. Three enzymatic components are involved: CPT-1, CPT-2 and carnitine acylcarnitine translocase (CATC) [27]. The fatty acids are activated by the acyl-CoA synthetase enzyme forming an activated complex (fatty acyl-CoA), with the carnitine-palmitoil-transferase (CPT-1) enzyme. This complex penetrates the mitochondrial membrane and reaches the intermembrane space. Acyl-CoA is regenerated with the release of carnitine in the CPT-2 reaction. Once it reaches the mitochondrial matrix, the long chain fatty acid (LCFA) is oxidized to generate adenosine triphosphate (ATP) through the $\beta$-oxidation of the fatty acids [27]. CLA supplementation would increase the concentration and activity of CPT-1. Thus, collectively, the increased lipolysis, the reduction of lipase lipoprotein activity and increased carnitine-palmitoil-transferase-1 (CAT-1) activity lead to the reduction of the accumulation of fatty acids in the adipose and muscle tissues. These action mechanisms are those most discussed by the researchers [8]. Inside the mitochondria the fatty acids are oxidized by $\beta$-oxidation reactions and Cycle of Krebs (CK), releasing the $\mathrm{H}^{+}$and ewhich are carried $\left(\mathrm{NADH}^{+2}\right.$ and $\left.\mathrm{FADH}_{2}\right)$ to the respiratory chain (1). The gradient of $\mathrm{H}^{+}$and e- between the intermembrane space and the matrix determines its return passing by the ATP synthase protein (2) with a synthesis of ATP (coupled reaction) or by the uncoupling protein (3) producing heat.

However, the rationale that CLA stimulates lipolysis only by increasing CPT-1 is valid (and limited) for situations in which $\beta$-oxidation (capacity to generate ATP through the successive break down of fatty acid carbon) is more efficient than the transport of the fatty acyl-CoA complex to the mitochondrial matrix. In this way it is possible and logical to say that CLA supplementation (increasing CPT-1 concentration and activation) would only have a potential effect on physically active individuals,

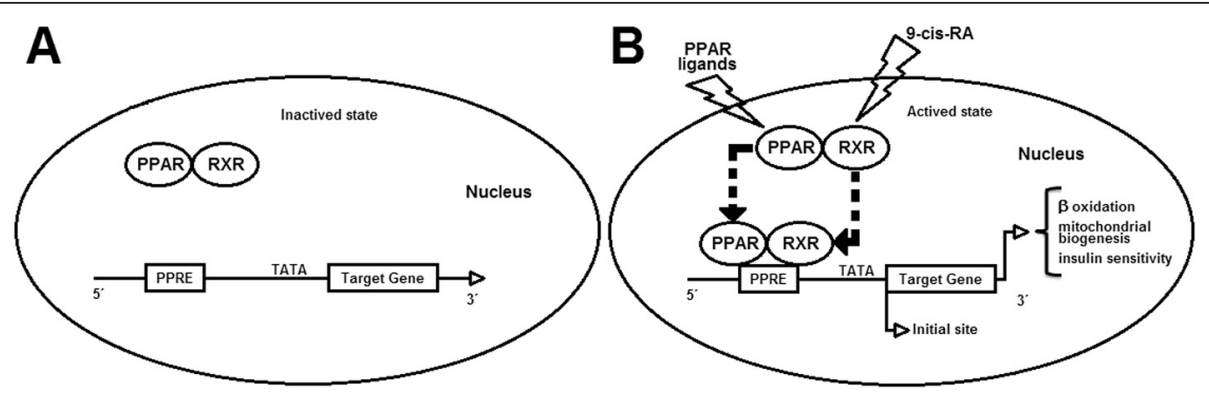

Fig. 2 Mechanism for transcriptional activation by PPAR. Panel a shows the inactivated state, without gene transcriptional of any target genes. Panel $\mathbf{b}$ shows the activation of PPAR by PPAR ligands and RXR by 9-cis-RA (9-cis-retinoic acid), thereby stimulating target genes transcription by binding to specific DNA sequence (peroxisome proliferators - PPRE) leading to increased $\beta$-oxidation, mitochondrial biogenesis and insulin sensitivity 
particularly for those whose $\beta$-oxidation is more efficient than the transport of fatty acid itself to the mitochondrial matrix.

On the other hand, weight loss with CLA supplementation could be explained by its association with the uncoupling protein of the respiratory chain (UCP), potentiating the $\beta$-oxidation capacity [28]. The respiratory chain or electron transport chain is formed by a series of transport compounds located in the inner membrane of the mitochondria. The last of these of these compounds is called cytochrome-oxidase, the only one that presents all necessary conditions to deliver electrons directly to the $\mathrm{O}_{2}$. However, not all of the energy contained in the electrons will be contained in the ATP, since part of it evolves as heat to maintain the spontaneity of the successive transfers. As the electrons flow through the respiratory chain, they lose their free energy. Part of this energy can be picked up and stored to produce ATP from ADP and inorganic phosphate. The rest of the free energy, which is not taken up for ATP re-synthesis, is released in the form of heat, increasing UCP activity $[29,30]$.

UCPs are proteins found in the inner mitochondrial membrane that allow proton flow from the intermembrane space to the mitochondrial matrix. However, the return of protons to the mitochondrial matrix does not lead to energy storage in the form of ATP thereby releasing heat. UCP-1, also known as thermogenin, often speeds up the proton return to the mitochondrial matrix so that energy from Krebs cycle, originated from the oxidation of energetic substrates (including lipids), is lost in the form of heat (which can lead to weight loss if this UCP is stimulated) [31].

UCPs can be subdivided into UCP-1, UCP-2 and UCP3 . They differ in their distribution among tissues and possible function. UCP1 is exclusively expressed in brown adipose tissue; UCP3 is expressed in muscle and a number of other tissues; and UCP2 is expressed in a variety of tissues including white adipose tissue (WAT) and is the most highly expressed UCP [32]. These proteins can exert a thermogenic effect and are capable of depleting the proton gradient, but their functions are not yet completely clear $[13,26,31]$.

UCP-1 is responsible for lipid oxidation and heat production in brown adipose tissue (abundant in hibernating animals). Human adults have higher levels of white adipose tissue and have UCP-2 and UCP-3, which appears to be related to heat generation. Other UCPs (UCP-4, for instance) are also being investigated [31]. The administration of thyroid hormones leads to respiratory chain uncoupling, which might be explained by an increase in UCPs [33]. Moreover, lipolysis resulting from fasting appears to stimulate UCPs, and the interaction of fatty acids with PPAR seems to increase the expression of UCPs [34].
Supplementation with a CLA mixture or 10,12 CLA in rodents has been shown to induce UCP2 transcription in WAT $[32,35,36]$, but whether it plays a role in energy dissipation is unclear. It would appear that CLA interacts with PPAR $\gamma$, increases CTP-1 and expression of UCP-1 resulting in greater capacity for lipolysis and fat mass weight reduction [28].

\section{Evidences from experimental animal}

According to Gaze et al. [37], the effect of CLA is not the same in all animal models. Rats supplemented with $0.5 \%$ of CLA, for instance, presented a small, but fast (7 days) reduction of adipose tissue, compared to mice [37].

Botelho [8] evaluated the effects of supplementation with CLA on the body composition of healthy Wistar rats supplemented for 3 weeks with CLA at the concentrations of $1 \%, 2 \%$ and $4 \%$ on the daily consumption of the diet + control group ( $2 \%$ linoleic acid). At the end of the period, the groups that were supplemented at a concentration of $2 \%$ and $4 \%$ with CLA presented a greater body fat reduction compared to the control group [8].

Other researchers evaluated coconut oil, maize oil and CLA. In this study 28 rats were allocated to 4 different diets: supplementation with coconut oil, coconut oil and CLA, maize oil and maize oil and CLA. After 28 days, total cholesterol, HDL-c and triglycerides were evaluated. It was found that the triglycerides diminished in the diet supplemented with coconut oil and CLA, and HDL-c diminished with the maize oil diet. The total cholesterol concentrations were lowest in the rats on the coconut oil and CLA diet, but not in the diet with maize oil and CLA. This study suggests that the CLA might diminish adiposity and improve the lipid profile under some conditions [9].

\section{Evidences from human studies}

In recent years, CLA supplementation has also been used in sports, aiming to reduce body fat and possibly improve performance [38]. Furthermore, other supposed benefits include improved lipid profile [39] and/or antiinflammatory effects [40] that can reduce oxidative stress [41] and ameliorate insulin signaling [42], among others. Collectively, these mechanisms improve body composition and energetic metabolism. Table 1 shows 16 randomized clinical trials (RCT) using CLA as intervention (last 5 years, Pubmed database) on putative benefits. It is possible to see that $9 \mathrm{RCTs}$, from a total of 16 , showed no benefit on aspects related to CLA supplementation. In addition, the studies shown in Table 1, other evidence from human studies are shown below.

Few studies have evaluated changes in body composition with the use of CLA alone or in combination with physical exercise in humans. Blankson et al. [10] showed 
Table 1 Randomized clinical trials using CLA as intervention on putative benefits

\begin{tabular}{|c|c|c|c|c|}
\hline Author & Sampling & Study design & Intervention & Results \\
\hline BACHMAIR et al., 2015 [55] & $\begin{array}{l}\text { Forty-three healthy adults at } \\
\text { low to moderate risk of } \\
\text { cardiovascular disease }\end{array}$ & $\begin{array}{l}\text { Double-blind, placebo } \\
\text { controlled study }\end{array}$ & $\begin{array}{l}\text { Sample received } 4 \mathrm{~g} / \text { day of CLA80:20 } \\
\text { or placebo for two weeks }\end{array}$ & $\begin{array}{l}\text { No clear evidence was found for inhibition } \\
\text { or activation of platelet function as well as } \\
\text { inflammation by CLA80:20 in a low to } \\
\text { moderate cardiovascular risk group. }\end{array}$ \\
\hline JENKINS et al., 2014a [56] & $\begin{array}{l}\text { Thirty-four untrained to } \\
\text { moderately trained men }\end{array}$ & $\begin{array}{l}\text { Double-blind, placebo } \\
\text { controlled study }\end{array}$ & $\begin{array}{l}\text { Randomly assigned to either a CLA } \\
\text { (Clarinol A-80; } n=18 \text { ) or placebo } \\
\text { (PLA; sunflower oil; } n=16 \text { ) group } \\
\text { Prior to and following } 6 \text { weeks of } \\
\text { aerobic training }\left(50 \% \mathrm{VO}_{2} \text { peak for }\right. \\
30 \text { min, twice per week) and } \\
\text { supplementation ( } 5.63 \mathrm{~g} \text { of total }\end{array}$ & $\begin{array}{l}\text { Serum triacylglycerol concentrations were } \\
\text { lower }(p<0.05) \text { in the } C L A \text { than the PLA } \\
\text { group. For } \mathrm{VO}_{2} \text { peak and glucose, there } \\
\text { were group } \times \text { time interactions }(p<0.05) \text {. } \\
\text { However, post-hoc statistical tests did not } \\
\text { reveal any differences between the CLA } \\
\text { and PLA groups. }\end{array}$ \\
\hline
\end{tabular}

JENKINS et al., 2014b [57] Thirty-four untrained to moderately trained men

ARYAEIAN et al., 2014 [58] Seventy eight adults with active rheumatoid arthritis

EFTEKHARI et al., 2014 [59] Ninety atherosclerotic patients

MOHAMMADZADEH et al., Thirty four volunteers patients 2013 [60] with rectal cancer clinical randomized trial

Double-blind, placebo controlled study

Double-blind clinical trial

Randomized, double-blind, placebo-controlled pilot supplementation (5.63 g of total

CLA isomers [of which $2.67 \mathrm{~g}$ was

9-cis, 11-trans and $2.67 \mathrm{~g}$ was

10-trans, 12-cis] or $7.35 \mathrm{~g}$ high

oleic sunflower oil per day)

Randomly assigned to either a CLA

(Clarinol A-80; $n=17$ ) or placebo

(PLA; sunflower oil; $n=16$ ) group.

Before and after 6 weeks of aerobic training $\left(50 \% \mathrm{VO}_{2}\right.$ peak for $30 \mathrm{~min}$, twice per week) and supplementation (8 $\mathrm{ml} \mathrm{CLA} \mathrm{or} \mathrm{PLA} \mathrm{per} \mathrm{day),} \mathrm{each} \mathrm{subject}$ completed an incremental cycle ergometer test, maximal number of sit-ups in $1 \mathrm{~min}$, and the standing long jump

Four groups receiving one of the following daily supplement for 3 months; group C: $2.5 \mathrm{~g}$ CLAs, group E: $400 \mathrm{mg}$ Vitamin E, group CE: CLAs plus Vitamin E, group P: Placebo. Cytokines, matrix metalloproteinase (MMP-3) and citrullinated antibody (CCP-A)

Patients were classified into 3 groups receiving $3 \mathrm{~g} / \mathrm{d}$ CLA or $1920 \mathrm{mg} / \mathrm{d}$ $\omega 3$ or placebo for 2 months.

CLA group $(n=16)$, receiving $3 \mathrm{~g} C L A / d$ and placebo group $(n=18)$ receiving placebo capsules (sunflower oil) for 6 weeks
There were no differences between the CLA and PLA groups for the analysis of covarianceadjusted post-test mean values for physical working capacity, sit-ups, or standing long jump. The physical working capacity increased from pre- to post-training in the CLA $(p=0.003)$ and PLA $(p=0.003)$ groups. There were no differences from pre- to post-training for sit-ups and standing long jump in either the CLA or PLA groups. There was no effect of CLA on physical working capacity, maximum number of sit-ups or standing long jump.

Co-supplementation CLAs and Vitamin E may be effective in the level of inflammatory markers in rheumatoid arthritis patients.

Although CLA did not appear to have a significant effect on triglycerides, $\omega 3$ supplementation significantly reduced triglycerides level. Consumption of CLA and $\omega 3$ supplementation did not significantly affect HDL cholesterol, LDL cholesterol, and total cholesterol.

CLA supplementation improved inflammatory factors, MMP-2, and MMP-9 as biomarkers of angiogenesis and tumor invasion. It seems ang that CLA may provide new complementary treatment by reducing tumor invasion and resistance to cancer treatment in patients with rectal cancer. 
Table 1 Randomized clinical trials using CLA as intervention on putative benefits (Continued)

\begin{tabular}{lll}
\hline PENETO et al., 2013 [61] & $\begin{array}{l}\text { Twenty nine healthy adult } \\
\text { volunteers (nineteen women and } \\
\text { ten men, aged twenty two to } \\
\text { thirty six years) }\end{array}$ & Double-blind clinical trial \\
& \\
& \\
CARVALHO et al., 2013 & $\begin{array}{l}\text { Fourteen women diagnosed } \\
\text { [62] }\end{array}$ & $\begin{array}{l}\text { Randomized clinical trial, } \\
\text { withetabolic syndrome }\end{array}$
\end{tabular}

[62] with metabolic syndrome

BULUT et al., 2013 [63] Eighteen sedentary male volunteers

\begin{abstract}
$\begin{array}{ll}\text { LÓPEZ PLAZA, et al., } 2013 & \begin{array}{l}\text { Thirty eight volunteers } \\ (29 \mathrm{w}, 9 \mathrm{~m})\end{array} \\ \text { [64] } & \end{array}$ $(29 \mathrm{w}, 9 \mathrm{~m})$
\end{abstract}

ENGBERIN et al. 2012 [65] Sixty-one healthy volunteers

JOSEPH et al., 2011 [66]

Twenty seven volunteers with overweight, borderline hypercholesterolemic,
Randomized double blind experiment

A prospective, placebocontrolled, randomised double-blind, parallel clinical trial

Double-blind, placebo controlled study

\section{Double-blinded, 3-phase} crossover trial

CLA depletion was achieved through an 8-week period of restricted dairy fat intake (depletion phase; CLA intake was $5.2 \pm 5.8 \mathrm{mg} /$ day), followed by an 8-week period in which individuals consumed $20 \mathrm{~g} /$ day of butter naturally enriched with 9-cis, 11-trans CLA (repletion phase; CLA intake of $1020 \pm 167$ $\mathrm{mg} /$ day)

Participants received strawberry jam enriched or not with microencapsulated CLA (3 g/day) as a mixture of $38.57 \%$ 9-cis, 11-trans, and $39.76 \%$ 10-trans, 12-cis CLA. isomers associated with a hypocaloric diet for 90 days

Volunteers were randomly divided into CLA and placebo supplementation groups; both groups underwent daily supplementation of either $3 \mathrm{~g}$ CLA or $3 \mathrm{~g}$ placebo for 30 days and performed exercise on a bicycle ergometer 3 times per week

Volunteers consumed $200 \mathrm{ml} /$ day of skimmed milk with $3 \mathrm{~g}$ of CLAs or $3 \mathrm{~g}$ olive oil (placebo).

The diets were identical except for $7 \%$ of energy $(18.9 \mathrm{~g}$ in a diet of $10 \mathrm{MJ} /$ day) that was provided either by oleic acid, by industrial trans fatty acids or by 9-cis,

\section{1-trans CLA.}

Participants consumed under supervision in random order $3.5 \mathrm{~g} / \mathrm{d}$ of safflower oil (control), a 50:50 mixture of 10-trans, 12-cis, and 9-cis, 11-trans CLA:Clarinol G-80, and 9-cis, 11-trans isomer CLA
The intake of a 9-cis, 11-trans CLA-enriched butter by normal-weight beneficial changes in immune modulators associated with sub-clinical inflammation in overweight individuals.

There were no significant effects of CLA on the lipid profile or blood pressure. Mean plasma insulin concentrations were significantly lower in women supplemented with CLA, did not alter the waist circumference, but there was a reduction in body fat mass detected after 30 days, and had a reduced waist circumference

CLA is not more effective than exercise alone.

The consumption of skimmed milk enriched with $3 \mathrm{~g}$ of a 1:1 mixture of 9-cis, 11-trans and 10-trans, 12-cis for 24 weeks led to a decrease in body weight and total fat mass in healthy, overweight subjects who maintained habitual diets and exercise patterns. No adverse effects were observed

The effect of the CLA diet compared with the oleic acid diet was $0.11 \mathrm{~mm} \mathrm{Hg}(95 \%$ confidence interval: $-1.27,1.49)$ systolic and $-0.45 \mathrm{~mm} \mathrm{Hg}(-1.63,0.73)$ diastolic. Shortterm high intakes of 9-cis, 11-trans CLA do not affect blood pressure in healthy volunteers.

Compared with the control treatment, the CLA treatments did not affect changes in body weight, body composition, or blood lipids. In addition CLA did not affect the $\beta$-oxidation rate of fatty acids or induce significant alterations in the safety markers tested. 
Table 1 Randomized clinical trials using CLA as intervention on putative benefits (Continued)

\begin{tabular}{|c|c|c|c|c|}
\hline $\begin{array}{l}\text { MICHISHITA et al., } 2010 \\
\text { [67] }\end{array}$ & Forty-one healthy subjects & $\begin{array}{l}\text { Single-centre, randomized, } \\
\text { double-blind, placebo- } \\
\text { controlled trial }\end{array}$ & $\begin{array}{l}\text { Subjects were randomized to receive either } \\
\text { placebo or one of three test supplements: } \\
\text { amino acid mixture } 0.76 \mathrm{~g} / \mathrm{day} \text {; amino acid } \\
\text { mixture } 1.52 \mathrm{~g} / \mathrm{day} \text {; or amino acid mixture } \\
1.52 \mathrm{~g} / \text { day coadministered with conjugated } \\
\text { linoleic acid } 1.6 \mathrm{~g} / \text { day and exercises for a period } \\
\text { of } 12 \text { weeks }\end{array}$ & $\begin{array}{l}\text { The results suggest that ingestion of these } \\
\text { supplements might enhance the fat-burning } \\
\text { effects of exercise. }\end{array}$ \\
\hline WANDERS et al., 2010 [68] & $\begin{array}{l}\text { Sixty-one healthy women } \\
\text { and men }\end{array}$ & $\begin{array}{l}\text { Double-blind, placebo } \\
\text { controlled study }\end{array}$ & $\begin{array}{l}\text { It was provided either by oleic acid, by } \\
\text { industrial trans fatty acids or by a mixture } \\
\text { of } 80 \% \text {-cis, } 11 \text {-trans and } 20 \% 10 \text {-trans, } \\
12 \text {-cis CLA. }\end{array}$ & $\begin{array}{l}\text { High intakes of an } 80: 20 \text { mixture of 9-cis, } \\
11 \text {-trans, and } 10 \text {-trans, } 12 \text {-cis CLA raise the } \\
\text { total to HDL cholesterol ratio in healthy } \\
\text { volunteers. The effect of CLA may be } \\
\text { somewhat less than that of industrial } \\
\text { trans fatty acids. }\end{array}$ \\
\hline SLUIJS et al., 2010 [69] & Four hundred and one & $\begin{array}{l}\text { Double-blind, randomized, placebo- } \\
\text { controlled and parallel-group trial }\end{array}$ & $\begin{array}{l}\text { Subjects receive either } 4 \mathrm{~g} \text { CLA/d ( } 2.5 \mathrm{~g} \text { 9-cis, } \\
11 \text {-trans CLA/d and } 0.6 \mathrm{~g} 10 \text {-trans, } 12 \text {-cis } \\
\text { CLA/d) or placebo supplements for } 6 \text { months }\end{array}$ & $\begin{array}{l}\text { There was no effect of 9-cis, 11-trans CLA } \\
\text { supplementation on blood pressure, body } \\
\text { composition, insulin resistance, or } \\
\text { concentrations of lipid, glucose, and C- } \\
\text { reactive protein. }\end{array}$ \\
\hline $\begin{array}{l}\text { SYVERTSEN et al., } 2007 \\
\text { [70] }\end{array}$ & $\begin{array}{l}\text { One hundred and eighteen } \\
\text { volunteers }\end{array}$ & $\begin{array}{l}\text { Randomized, double-blind, } \\
\text { placebo-controlled trial }\end{array}$ & $\begin{array}{l}\text { Supplementation with either placebo } \\
\text { (olive oil) or CLA (Clarinol) for } 6 \text { months }\end{array}$ & $\begin{array}{l}\text { CLA does not affect glucose metabolism } \\
\text { or insulin sensitivity in a population of } \\
\text { overweight or obese volunteers. }\end{array}$ \\
\hline
\end{tabular}


that CLA may reduce the percentage of fat in humans over a 12-months period, besides increasing the lean mass and not presenting any additional effect at doses above $3.4 \mathrm{~g}$ of CLA per day. However since physical training was performed at the same time as the CLA was used, and the levels of exercise were different among the groups, it was not possible to evaluate whether the effect of the body changes was due to the use of CLA, exercise, or the combination of both.

Gaullier et al. [11] performed a 24-month randomized, double-blind placebo-controlled study, during which 6 capsules of gel were administered daily, totaling $4.5 \mathrm{~g}$ of CLA. The authors observed that the CLA supplementation for this period in overweight adults is well tolerated, and CLA reduces body fat in overweight humans and can help maintain the initial fat and weight losses over the long term [11].

As to gender, Santos-Zago et al. [20] showed the effect of body fat reduction on healthy, eutrophic women who consumed $3 \mathrm{~kg}$ of CLA per day, during 64 days. The results, however, were not significant, since CLA consumption during this period did not alter the women's body composition [20]. On the other hand, individuals with overweight and obesity, who consumed the amount of $3.4 \mathrm{~g}$ of CLA per day for 12 weeks reduced their body fat, as previously shown [10].

The responses to the different CLA isomers do not appear to present differences, although it was found that the 10-trans, 12-cis isomer increased the concentration of triglycerides and LDL cholesterol in a greater proportion in healthy men compared to the 9-cis, 11-trans isomer [21]. In a review study, obese men diagnosed with metabolic syndrome used CLA for 4 weeks. The final result was a reduction of the abdominal circumference, however other anthropometric measures did not undergo a relevant change [37].

A randomized, double blind, placebo-controlled study looked at the effects of CLA supplementation on body composition and weight loss for 12 weeks, in individuals with obesity or grade I obesity in the Chinese population. Bioelectric impedance was the method used to evaluate body composition changes during the study. Individuals randomly received $1.7 \mathrm{~g}$ of 9-cis, 11-trans and 10-trans, 12-cis of CLA $(n=30)$ or placebo $(n=33)$ in $200 \mathrm{ml}$ of sterilized milk twice a day. As a result it was found that the group supplemented with CLA presented a reduction of obesity and/or overweight besides other benefits, without evidence of adverse effects [18].

Kim et al. [43] tested the supplementation of CLA $2.4 \mathrm{~g} /$ day CLA mixture (36.9 \% of 9-cis, 11-trans and $37.9 \%$ of 10-trans, 12-cis) as an antioxidant agent in healthy overweight/obese Korean individuals. Eight weeks of conjugated linoleic acid supplementation has no effect on antioxidant status (plasma total radical- trapping antioxidant potential, lipid peroxidation, lipidsoluble antioxidant vitamin concentration, erythrocyte antioxidant enzyme - superoxide dismutase, catalase, glutathione peroxidase), and leukocyte DNA damage between the CLA, compared to placebo group.

Thirty-seven recreationally-trained women (mean $\mathrm{BMI}=25.1 \pm 3.4)$ were randomized for three dietary interventions: 1) a control diet (without changing their usual dietary habits); 2) a high-protein, low-calorie diet supplemented with protein gels (22 $\mathrm{g}$ of protein per serving), encapsulated thermogenic (Burn $\left.{ }^{\circ}\right)$, multivitamin (Balance ${ }^{\circ}$ ), and CLA (Tone ${ }^{\circ}$ ); and 3) a high-protein diet with isocaloric placebo supplements. After three weeks, women in the supplementation group had their body weight and percentage of body fat (assessed by DEXA and skinfolds) significantly decreased when compared to placebo or control diets. Despite these positive results, it is noteworthy the fact that CLA was used concomitant to other nutritional supplements, and it is thus difficult to assess its effect individually on body adiposity [44].

In another study, 101 moderately obese subjects who lost $>8 \%$ of their baseline body weight in a previous study were subsequently assigned to a 1-year double-blind CLA (3.4 g/day) or placebo (olive oil) supplementation regime in combination with a modest hypocaloric diet. The authors found no significant difference in body weight or body fat regain (assessed by DEXA) between the treatments; however, there was a significant increase in the number of leukocytes with CLA supplementation [45].

Individuals with type 2 diabetes mellitus (T2DM) using metformin (30 females and 26 males) were allocated to an eight-week randomized trial and stratified by sex, age and BMI into one of three groups: 1) $3 \mathrm{~g}$ CLA/ day $(3 \times 1 \mathrm{~g}$ capsules; a 50:50 isomer blend of 9-cis, 11trans and 10-trans, 12-cis CLA) plus 100 IU/day of vitamin E; 2) 3 g CLA/day plus vitamin E placebo; 3) or CLA placebo (soy bean oil) plus vitamin E placebo. By the end of the study there were no significant differences regarding body weight, body composition, glycemic index and inflammatory profile among the three groups; however, there was a trend toward an increase in malondialdehyde levels (a marker of oxidative stress) and decrease in apoB100 (linked to HDL-cholesterol levels) among those receiving CLA [46].

Thirty-five obese postmenopausal women with T2DM were also randomized to receive safflower oil $(8 \mathrm{~g} /$ day $)$ or CLA (6.4 g CLA isomers/day) in a 36-week randomized crossover trial (two 16-week diet periods separated by a 4-week washout period). DEXA analysis was used for the assessment of body composition. Supplementation with CLA reduced BMI and total adipose mass without changing lean mass; in contrast, safflower oil reduced trunk adipose mass, increased lean mass and significantly lowered fasting glucose. It is suggested that 
both oils have different effects on body composition in obese women with T2DM who are not also on a weightloss diet or exercise plan [47].

Finally, a meta-analysis that included 7 clinical assays in the final analysis for the purpose of evaluating the use of CLA during a long time did not show significant results to support changes in the body composition when using CLA for a longer period [48].

\section{Recommended dose}

Most of the studies were a mixture of the two predominant isomers, 9-cis, 11-trans and 10-trans, 12-cis, in equal proportions. The daily doses of CLA varied from 3 to $6 \mathrm{~g} /$ day, according to several studies and these doses appear safe [49]. Although some studies indicate that doses above $3.4 \mathrm{~g} /$ day would not have any additional effect, they suggest that there is a very great variation compared to the results due to different doses, type of isomer, and evaluation of the body composition, which makes it difficult to compare different studies $[10,18]$.

\section{Adverse effects}

Despite the positive effects of CLA supplementation on some health-related parameters, there are a few reports of possible adverse effects, mainly in rats and due to the 10-trans and 12-cis isomer. In the animal models procarcinogenic effects and of increased production of prostaglandins attributed to CLA 10-trans and 12-cis have been identified [50].

Other negative effect may be due to the increase in the lipid oxidation products (isoprostanes), besides the diminished leptin and greater probability of developing insulin resistance [51]. Studies also show undesirable effects in human beings as increased levels of triglycerides and LDL-cholesterol and reduction of the HDL levels, suggesting a negative alteration in the serum lipids profile [52]. Obese individuals also presented negative alterations in the glucose metabolism with insulin resistance in some studies $[53,54]$.

\section{Conclusions}

Despite studies on CLA supplementation for the purpose of investigating changes in body composition and other benefits, both in animals and in humans, they are very discordant. The capacity of CLA to alter the body composition positively by reducing the fat mass was proved in experimental models, and, in some studies on human beings. In fact, few studies have evaluated the use of CLA alone or in combination with physical exercise in humans, regarding changes in body composition. Therefore, the clinical evidence appears to be insufficient and not unanimous regarding the effects on body fat reduction and major side effects have already been described.

In this sense, the consumption of foods naturally enriched with CLA (and not from supplementation) during lifetime would be an alternative to reduce increased adiposity. Besides, it could reduce de risk of other diseases associated with obesity, since they would ensure the beneficial effects on body composition and would not add effects that are adverse to health.

\section{Competing interests}

The authors declare that they have no competing interests (financial and non-financial).

\section{Authors' contributions}

Each author has made a valuable contribution to the preparation of this manuscript: TEL was involved in conception and design of the paper, as well as drafting and editing the final document for publication. MRC and AC were equally involved in the collection of articles involving CLA, as well as drafting and editing the final document for publication. AM was involved in reviewing all parts of the final document for publication, in particular on nutritional issues. AML was involved in conception and design of the study, articles analysis, as well as writing, drafting and editing the final document for publication. All authors read and approved the final manuscript.

\section{Author details}

${ }^{1}$ Faculdade Sogipa de Educação Física, Porto Alegre, Brazil. ${ }^{2}$ Instituto de Cardiologia/Fundação Universitária de Cardiologia (IC/FUC), Porto Alegre, Brazil. '3niversidade Federal de Ciências da Saúde de Porto Alegre (UFCSPA), Porto Alegre, Brazil. ${ }^{4}$ Instituto de Cardiologia do Rio Grande do Sul, Av. Princesa Isabel, 395 Santana, 90620-001 Porto Alegre, RS, Brazil.

Received: 20 May 2015 Accepted: 4 September 2015

Published online: 17 September 2015

\section{References}

1. Hasler CM. Functional foods: benefits, concerns and challenges-a position paper from the american council on science and health. J Nutr. 2002;132:3772-81.

2. Hite $A H$, Bernstein LH. Functional foods: needs, claims, and benefits Nutrition. 2012:28:338-9.

3. Williamson C. Functional foods: what are the benefits? $\mathrm{Br} J$ Community Nurs. 2009;14:230-6.

4. Chen S, Osaki N, Shimotoyodome A. Green tea catechins enhance norepinephrine-induced lipolysis via a protein kinase A-dependent pathway in adipocytes. Biochem Biophys Res Commun. 2015. Epub ahead of print.

5. Roberfroid MB. Concepts and strategy of functional food science: the European perspective. Am J Clin Nutr. 2000;71:1660S-4S.

6. Oliveira RL, Ladeira MM, Barbosa MAAF, Assunção DMP, Matsushita M Santos GT, et al. Linoleic conjugated acid and fatty acids profile in the muscle and fat layer of water buffalo steers fed different fat sources. Braz J Vet Anim Sci. 2008;60:169-78.

7. Churruca I, Fernandez-Quintela A, Portillo MP. Conjugated linoleic acid isomers: differences in metabolism and biological effects. Biofactors. 2009:35:105-11.

8. Botelho AP, Santos-Zago LF, Reis SMPM, Oliveira AC. Conjugated linoleic acid suplementation decreased the body fat in Wistar rats. Braz J Nutr. 2005:18(4):561-565.

9. Kloss R, Linscheid J, Johnson A, Lawson B, Edwards K, Linder T, et al. Effects of conjugated linoleic acid supplementation on blood lipids and adiposity of rats fed diets rich saturated versus unsaturated fat. Pharmacol Res. 2005:51(6):503-7.

10. Blankson H, Stakkestad JA, Fagertun H, Thom E, Wadstein J, Gudmundsen O. Conjugated linoleic acid reduces body fat mass in overweight and obese humans. J Nutr. 2000;130:2943-8.

11. Gaullier JM, Halse J, Hoye K, Kristiansen K, Fafertun H, Vik H, et al, Supplementation with conjugated linoleic acid for 24 months is wel 
tolerated by and reduces body fat mass in healthy, overweight humans. J Nutr. 2005;135:778-84.

12. Campbell B, Kreider R. Conjugated linoleic acids. Curr Sports Med Rep. 2008; $7: 237-41$

13. Ryder JW, Portocarrero CP, Song XM, Cui L, Yu M, Combatsiaris T, et al. Isomer-specific antidiabetic properties of conjugated linoleic acid. Improved glucose tolerance, skeletal muscle insulin action, and UCP-2 gene expression. Diabetes. 2001;50:1149-57.

14. Kishino S, Ogawa J, Omura Y, Matsumura K, Shimizu S. Conjugated linoleic acid production from linoleic acid by lactic acid bacteria. J Am Oil Chem Soc. 2002;70:159-63.

15. Martins SV, Madeira A, Lopes PA, Pires VM, Alfaia CM, Prates JA, et al. Adipocyte membrane glycerol permeability is involved in the antiadipogenic effect of conjugated linoleic acid. Biochem Biophys Res Commun. 2015:458:356-61

16. Poirier H, Shapiro JS, Kim RJ, Lazar MA. Nutritional supplementation with trans-10, cis-12-conjugated linoleic acid induces inflammation of white adipose tissue. Diabetes. 2006;55:1634-41.

17. Whigham LD, Watras AC, Schoeller DA. Efficacy of conjugated linoleic acid for reducing fat mass: a meta-analysis in humans. Am J Clin Nutr. 2007:85:1203-11.

18. Chen SC, Lin YH, Huang HP, Hsu WL, Houng JY, Huang CK. Effect of conjugated linoleic acid supplementation on weight loss and body fat composition in a Chinese population. Nutrition. 2012;28:559-65

19. Kamphuis MMJW, Lejeune MPGM, Saris WHM, Westerterp-Plantenga MS. The effect of conjugated linoleic acid supplementation after weight loss on body weight regain, body composition, and resting metabolic rate in overweight subjects. Int J Obes. 2003;27:840-7.

20. Santos-Zago LF, Botelho AP, Oliveira AC. Effects of conjugated linoleic acid on animal metabolism: advances in research and perspectives for the future: [review]. Braz I Nutr. 2008;21(2):195-221.

21. McGowan MM, Eisenberg BL, Lewis LD, Froehlich HM, Wells WA, Eastman A, et al. A proof of principle clinical trial to determine whether conjugated linoleic acid modulates the lipogenic pathway in human breast cancer tissue. Breast Cancer Res Treat. 2013;138:175-83.

22. Reardon M, Gobern S, Martinez K, Shen W, Reid T, McIntosh M. Oleic acid attenuates trans-10, cis-12 conjugated linoleic acid-mediated inflammatory gene expression in human adipocytes. Lipids. 2012;47:1043-51.

23. Vaughan RA, Garcia-Smith R, Bisoffi M, Conn CA, Trujillo KA. Conjugated linoleic acid or omega 3 fatty acids increase mitochondrial biosynthesis and metabolism in skeletal muscle cells. Lipids Health Dis. 2012;11:142.

24. Abduljabbar R, Al-Kaabi MM, Negm OH, Jerjees D, Muftah AA, Mukherjee A et al. Prognostic and biological significance of peroxisome proliferatoractivated receptor-gamma in luminal breast cancer. Breast Cancer Res Treat. 2015;150:511-22.

25. Tavares V, Hirata MH, Hirata RDC. Peroxisome proliferator-activated receptor gamma (PPARgamma): molecular study in glucose homeostasis, lipid metabolism and therapeutic approach. Arch Endocrinol Metabol. 2007:51:526-33.

26. Boschini RP, Garcia Júnior JR. UCP2 and UCP3 genic expression: regulation by food restriction, fasting and physical exercise. Braz I Nutr. 2005;18:753-64.

27. Yamashita AS, Lira FS, Lima WP, Carnevali LC, Gonçalves DC, Tavares FL, et al. Influence of aerobic physical training in the motochondrial transport of long chain fatty acids in the skeletal muscle: role of the carnitine palmitoil transferase. Brazilian journal of sports medicine. 2008;14(2):150-154.

28. Peters JM, Park Y, Gonzalez FJ, Pariza MW. Influence of conjugated linoleic acid on body composition and target gene expression in peroxisome proliferator-activated receptor a-null mice. Biochim Biophys Acta. 2001;1533(3):233-42.

29. Toda C, Diano S. Mitochondrial UCP2 in the central regulation of metabolism. Best Pract Res Clin Endocrinol Metab. 2014;28(5):757-64.

30. Sugimoto S, Nakajima H, Kodo K, Mori J, Matsuo K, Kosaka K, et al. Miglitol increases energy expenditure by upregulating uncoupling protein 1 of brown adipose tissue and reduces obesity in dietary-induced obese mice. Nutr Metab (Lond). 2014;11(1):14.

31. Busiello RA, Savarese S, Lombardi A. Mitochondrial uncoupling proteins and energy metabolism. Front Physiol. 2015;6:36.
32. Kennedy A, Martinez K, Schmidt S, Mandrup S, LaPoint K, Mclntosh M. Antiobesity mechanisms of action of conjugated linoleic acid. J Nutr Biochem. 2010;21(3):171-9.

33. Ribeiro MO, Bianco SD, Kaneshige M, Schultz JJ, Cheng SY, Bianco AC, et al. Expression of uncoupling protein 1 in mouse brown adipose tissue is thyroid hormone receptor-beta isoform specific and required for adaptive thermogenesis. Endocrinology. 2010;151(1):432-40.

34. Aubert J, Champigny O, Saint-Marc P, Negrel R, Collins S, Ricquier D, et al. Up-regulation of UCP-2 gene expression by PPAR agonists in preadipose and adipose cells. Biochem Biophys Res Commun. 1997;238:606-11.

35. Takahashi Y, Kushiro M, Shinohara K, Ide T. Dietary conjugated linoleic acid reduces body fat mass and affects gene expression of proteins regulating energy metabolism in mice. Comp Biochem Physiol B Biochem Mol Biol. 2002;133(3):395-404.

36. Nagao K, Wang YM, Inoue N, Han SY, Buang Y, Noda T, et al. The 10trans, 12cis isomer of conjugated linoleic acid promotes energy metabolism in OLETF rats. Nutrition. 2003;19(7-8):652-56.

37. Gaze BS, Nanci DP, Oliveira VAJ, Clemente M. Effect of the supplementation of conjugated linoleic acid (CLA) and the loss of weight in animals and human beings. Revista Brasileira de Obesidade, Nutrição e Emagrecimento. 2007;:1:48-55.

38. Barone R, Macaluso F, Catanese P, Marino Gammazza A, Rizzuto L, Marozzi $P$, et al. Endurance exercise and conjugated linoleic acid (CLA) supplementation up-regulate CYP17A1 and stimulate testosterone biosynthesis. PLoS One. 2013;8:e79686.

39. Agueda M, Zulet MA, Martínez JA. Effect of conjugated linoleic acid (CLA) on human lipid profile. Arch Latinoam Nutr. 2009;59(3):245-52.

40. Viladomiu M, Hontecillas R, Bassaganya-Riera J. Modulation of inflammation and immunity by dietary conjugated linoleic acid. Eur J Pharmacol. 2015;2999(15):459-8.

41. Eftekhari MH, Aliasghari F, Babaei-Beigi MA, Hasanzadeh J. Effect of conjugated linoleic acid and omega-3 fatty acid supplementation on inflammatory and oxidative stress markers in atherosclerotic patients. ARYA Atheroscler. 2013;9(6):311-8.

42. Evans JL, Maddux BA, Goldfine ID. The molecular basis for oxidative stressinduced insulin resistance. Antioxid Redox Signal. 2005;7(7-8):1040-52.

43. Kim J, Paik HD, Shin MJ, Park E. Eight weeks of conjugated linoleic acid supplementation has no effect on antioxidant status in healthy overweight/ obese Korean individuals. Eur J Nutr. 2012;51:135-41.

44. Falcone PH, Tai CY, Carson LR, Joy JM, Mosman MM, Vogel RM, et al. Subcutaneous and segmental fat loss with and without supportive supplements in conjunction with a low-calorie high protein diet in healthy women. PLoS One. 2015;10:e0123854.

45. Larsen TM, Toubro S, Gudmundsen O, Astrup A. Conjugated linoleic acid supplementation for 1 y does not prevent weight or body fat regain. Am J Clin Nutr. 2006;83(3):606-12.

46. Shadman Z, Taleban FA, Saadat N, Hedayati M. Effect of conjugated linoleic acid and vitamin E on glycemic control, body composition, and inflammatory markers in overweight type2 diabetics. J Diabetes Metab Disord. 2013;12:42.

47. Norris LE, Collene AL, Asp ML, Hsu JC, Liu LF, Richardson JR, et al. Comparison of dietary conjugated linoleic acid with safflower oil on body composition in obese postmenopausal women with type 2 diabetes mellitus. Am J Clin Nutr. 2009;90:468-76.

48. Onakpoya IJ, Posadzki PP, Watson LK, Davies LA, Ernst E. The efficacy of long-term conjugated linoleic acid (CLA) supplementation on body composition in overweight and obese individuals: a systematic review and meta-analysis of randomized clinical trials. Eur J Nutr. 2012;51:127-34.

49. Iwata T, Kamegai T, Yamauchi-Sato Y, Ogawa A, Kasai M, Aoyama T, et al. Safety of dietary conjugated linoleic acid (CLA) in a 12-weeks trial in healthy overweight Japanese male volunteers. J Oleo Sci. 2007;56:517-25.

50. Wendel AA, Purushotham A, Liu LF, Belury MA. Conjugated linoleic acid fails to worsen insulin resistance but induces hepatic steatosis in the presence of leptin in ob/ob mice. J Lipid Res. 2008;49:98-106.

51. Cooper MH, Miller JR, Mitchell PL, Currie DL, McLeod RS. Conjugated linoleic acid isomers have no effect on atherosclerosis and adverse effects on lipoprotein and liver lipid metabolism in apoE-/- mice fed a highcholesterol diet. Atherosclerosis. 2008;200:294-302.

52. Funck LG, Barrera-Arellano D, Block JM. Conjugated linoleic acid (CLA) and its relationship with cardiovascular disease and associated risk factors. Arch Latinoam Nutr. 2006;56:123-34. 
53. Kennedy A, Martinez K, Chung S, LaPoint K, Hopkins R, Schmidt SF, et al. Inflammation and insulin resistance induced by trans-10, cis-12 conjugated linoleic acid depend on intracellular calcium levels in primary cultures of human adipocytes. J Lipid Res. 2010;51:1906-17.

54. Kennedy A, Overman A, Lapoint K, Hopkins R, West T, Chuang CC, et al. Conjugated linoleic acid-mediated inflammation and insulin resistance in human adipocytes are attenuated by resveratrol. J Lipid Res. 2009;50(2):225-32

55. Bachmair EM, Wood SG, Keizer HG, Horgan GW, Ford I, de Roos B. Supplementation with a 9c,11 t-rich conjugated linoleic acid blend shows no clear inhibitory effects on platelet function in healthy subjects at low and moderate cardiovascular risk: a randomized controlled trial. Mol Nutr Food Res. 2015;59:741-50.

56. Jenkins ND, Buckner SL, Baker RB, Bergstrom HC, Cochrane KC, Weir JP, et al. Effects of 6 weeks of aerobic exercise combined with conjugated linoleic acid on the physical working capacity at fatigue threshold. J Strength Cond Res. 2014;28:2127-35.

57. Jenkins ND, Buckner SL, Cochrane KC, Bergstrom HC, Goldsmith JA, Weir JP, et al. CLA supplementation and aerobic exercise lower blood triacylglycerol, but have no effect on peak oxygen uptake or cardiorespiratory fatigue thresholds. Lipids. 2014;49:871-80.

58. Aryaeian N, Djalali M, Shahram F, Djazayery A, Eshragian MR. Effect of conjugated linoleic Acid, vitamin E, alone or combined on immunity and inflammatory parameters in adults with active rheumatoid arthritis: a randomized controlled trial. Int J Prev Med. 2014;5:1567-77.

59. Eftekhari MH, Aliasghari F, Beigi MA, Hasanzadeh J. The effect of conjugated linoleic acids and omega-3 fatty acids supplementation on lipid profile in atherosclerosis. Adv Biomed Res. 2014;9:3-15.

60. Mohammadzadeh M, Faramarzi E, Mahdavi R, Nasirimotlagh B, Asghari JM. Effect of conjugated linoleic acid supplementation on inflammatory factors and matrix metalloproteinase enzymes in rectal cancer patients undergoing chemoradiotherapy. Integr Cancer Ther. 2013;12:496-502.

61. Penedo LA, Nunes JC, Gama MA, Leite PE, Quirico-Santos TF, Torres AG. Intake of butter naturally enriched with cis9, trans 11 conjugated linoleic acid reduces systemic inflammatory mediators in healthy young adults. J Nutr Biochem. 2013;24:2144-51.

62. Carvalho RF, Uehara SK, Rosa G. Microencapsulated conjugated linoleic acid associated with hypocaloric diet reduces body fat in sedentary women with metabolic syndrome. Vasc Health Risk Manag. 2012;8:661-7.

63. Bulut S, Bodur E, Colak R, Turnagol H. Effects of conjugated linoleic acid supplementation and exercise on post-heparin lipoprotein lipase, butyrylcholinesterase, blood lipid profile and glucose metabolism in young men. Chem Biol Interact. 2013;203:323-9.

64. López-Plaza B, Bermejo LM, Koester Weber T, Parra P, Serra F, Hernández M, et al. Effects of milk supplementation with conjugated linoleic acid on weight control and body composition in healthy overweight people. Nutr Hosp. 2013;28:2090-8.

65. Engberink MF, Geleijnse JM, Wanders AJ, Brouwer IA. The effect of conjugated linoleic acid, a natural trans fat from milk and meat, on human blood pressure: results from a randomized crossover feeding study. J Hum Hypertens. 2012;26:127-32.

66. Joseph SV, Jacques H, Plourde M, Mitchell PL, McLeod RS, Jones PJ. Conjugated linoleic acid supplementation for 8 weeks does not affect body composition, lipid profile, or safety biomarkers in overweight, hyperlipidemic men. J Nutr. 2011;141:1286-91.

67. Michishita T, Kobayashi S, Katsuya T, Ogihara T, Kawabuchi K. Evaluation of the antiobesity effects of an amino acid mixture and conjugated linoleic acid on exercising healthy overweight humans: a randomized, double-blind, placebo-controlled trial. J Int Med Res. 2010;38:844-59.

68. Wanders AJ, Brouwer IA, Siebelink E, Katan MB. Effect of a high intake of conjugated linoleic acid on lipoprotein levels in healthy human subjects. PLoS One. 2010;5:e9000.

69. Sluijs I, Plantinga Y, de Roos B, Mennen LI, Bots ML. Dietary supplementation with cis-9, trans-11 conjugated linoleic acid and aortic stiffness in overweight and obese adults. Am J Clin Nutr. 2010;91:175-83.

70. Syvertsen C, Halse J, Høivik HO, Gaullier JM, Nurminiemi M, Kristiansen K, et al. The effect of 6 months supplementation with conjugated linoleic acid on insulin resistance in overweight and obese. Int J Obes (Lond). 2007;31:1148-54

\section{Submit your next manuscript to BioMed Central and take full advantage of:}

- Convenient online submission

- Thorough peer review

- No space constraints or color figure charges

- Immediate publication on acceptance

- Inclusion in PubMed, CAS, Scopus and Google Scholar

- Research which is freely available for redistribution

Submit your manuscript at www.biomedcentral.com/submit 